\title{
Catabolic Fingerprinting and Diversity of Bacteria in Mollic Gleysol Contaminated with Petroleum Substances
}

\author{
Agnieszka Wolińska ${ }^{1}$, Anna Gałązka ${ }^{2, *}$, Agnieszka Kuźniar ${ }^{1}$, Weronika Goraj ${ }^{1}$, \\ Natalia Jastrzębska ${ }^{1}$, Jarosław Grządziel ${ }^{2}$ (D) and Zofia Stępniewska ${ }^{1}$ \\ 1 Department of Biochemistry and Environmental Chemistry, The John Paul II Catholic University of Lublin, \\ Konstantynów 1 I Str., 20-708 Lublin, Poland; awolin@kul.pl (A.W.); agawoloszyn@kul.pl (A.K.); \\ weronika.goraj@kul.lublin.pl (W.G.); ajastrzebska@kul.lublin.pl (N.J.); zstepniewska@kul.lublin.pl (Z.S.) \\ 2 Department of Agriculture Microbiology, Institute of Soil Science and Plant Cultivation, Czartoryskich 8 Str., \\ 24-100 Puławy, Poland; jgrzadziel@iung.pulawy.pl \\ * Correspondence: agalazka@iung.pulawy.pl; Tel.: +48-47-86-950
}

Received: 18 September 2018; Accepted: 13 October 2018; Published: 18 October 2018

\begin{abstract}
This study focused on the determination of both catabolic and genetic fingerprinting of bacteria inhabiting soil contaminated with car fuels. A surface layer $(0-20 \mathrm{~cm})$ of Mollic Gleysol was used for the experiment and was contaminated with car fuels-unleaded 95-octane petrol and diesel at a dose of $15 \mathrm{~g}$ per $10 \mathrm{~g}$ of soil. The experiment lasted 42 days and was performed at $20{ }^{\circ} \mathrm{C}$. The metabolic potential of soil bacterial communities was evaluated using the Biolog EcoPlate system. The results demonstrated that petroleum substances influenced the structure of the microbial populations and their catabolic activity. The Arthrobacter, Paenibacillus, and Pseudomonas genera were found in diesel-contaminated soil, whilst Bacillus and Microbacterium were found in petrol-contaminated soil. Rhodococcus species were identified in both variants of impurities, suggesting the widest capability of car fuel degradation by this bacterial genus. The contamination with unleaded 95-octane petrol caused rapid inhibition of the metabolic activity of soil bacteria in contrast to the diesel treatment, where high metabolic activity of bacteria was observed until the end of the incubation period. Higher toxicity of petrol in comparison with diesel car fuel was evidenced.
\end{abstract}

Keywords: Biolog EcoPlate system; biodiversity; petroleum contaminants; soil; diesel; petrol

\section{Introduction}

Petroleum hydrocarbons (PHs) are common fuels used in extremely large quantities and represent a serious problem when released into the environment [1-3] because they contain n-alkanes, i.e., aliphatic and aromatic compounds [4]. Accidental release of PHs usually results in their persistence in soil [5-7] for decades because their biodegradation process occurs very slowly due to their recalcitrant nature [8]. The major sources of $\mathrm{PH}$ soil contamination are accidents during petroleum transfer, refinery wastes released into the environment, or petroleum leakage from pipelines [9]. Moubaser et al. [10] have reported that many PHs are usually highly toxic, carcinogenic, and mutagenic for both soil microorganisms and humans. The danger posed by the presence of PHs in soil is connected with their inherent properties: volatility and solubility [11]. PHs represent bioresistant organic compounds that can inhibit the metabolism of aerobic bacteria [12]. Consequently, they can exert a toxic effect on soil biodiversity and a negative impact on plants and soil health $1[2,13]$. Therefore, effective removal of PHs from the environment is crucial $[11,14]$.

The risk posed by $\mathrm{PH}$ soil contaminants can be reduced by the application of indigenous microorganisms dedicated to bioremediation processes $[3,13,15]$. Being in intimate contact with the 
soil, microorganisms are known to be the best indicators of soil pollution [13]. To date, various methods have been recommended to remediate polluted soil, i.e., chemical oxidation, thermal treatment, and bioremediation [11]. Soil microorganisms are economically feasible and are an effective solution for soil clean up [1,3,4]. Soil microorganisms break down complex compounds (i.e., PHs) and release inorganic nutrients that are available to plants [14,16]. In ideal conditions, PHs are completely biodegraded to carbon dioxide and water (products that are innocuous to humans and the environment); however, more frequently, biodegradation is not complete [4]. Generally, microorganisms in contaminated soil should adapt to environmental conditions as an effect of genetic mutations [3] and induction of specific enzymes, i.e., oxygenases, hydrolases, and oxidoreductases [6,17]. Nevertheless, it should be remembered that introduced microorganisms do not often survive when added to soil [1]. Therefore, introduction of new microflora dedicated to bioremediation should always be preceded by identification of autochthonic bacteria inhabiting the soil environment that use hydrocarbon pollution as a carbon source for their metabolic pathway $[1,18,19]$.

The best-known bacteria that are able to degrade PHs include the following genera: Arthrobacter, Acinetobacter, Bacillus, Brachybacterium, Corynebacterium, Geobacillus, Nocardia, Klebsiella, Mycobacterium, Microbacterium, Pseudomonas, Micrococcus, and Rhodococcus [19-24]. Similarly, Ralstonia and Burkholderia have been identified as PH degraders [25]. Borowik et al. [7] have suggested that the precise estimation of the effect of petroleum substances on the natural environment is very difficult. The main reason is that the proportions between fast- and slow-growing bacteria in PH-contaminated soils are usually variable [26], and knowledge of microbial succession is necessary for soil purification from petroleum contaminants [7].

The Biolog EcoPlate technique is recommended to indicate viable microorganisms and to perform metabolic fingerprinting $[16,27,28]$. Since microorganisms usually react quickly to any environmental disturbances and stresses, changes in their metabolic activity could be an early signal of alterations in the ecosystem [16]. The Biolog EcoPlate is a redox method for which the variability in the rate of colour development depending on the microbial community structure indicates the rate of utilization of carbon substrates preferred by soil microbes [16]. The method is appropriate and thus recommended for the evaluation of the microbial structure in contaminated and uncontaminated sites on the basis of differences in metabolic response [16]. Yet, it should be pointed out that the Biolog technique investigates the functional diversity of the part of microbial community which is metabolically active and able to grow in plate conditions [16].

Therefore, our principal goal was to evaluate a 6-week impact of car fuel contaminants on both metabolic activity and microbial community structure in order to gain knowledge of autochthonic microflora that is able to survive in the presence of these impurities. Additionally, recognition of differences in the microbial structure depending on the car fuel type (petrol and diesel) was also studied. In our previous study, we examined the effect of petroleum-derived substances (petrol, diesel, and new and used engine oils) on selected enzymatic activity and microbial structure as a result of 1-week soil contamination [19]. In the current work, the period of petroleum impact on microorganisms was extended to 6 weeks to determine the long-term effects of pollutants on soil bacteria.

\section{Materials and Methods}

\subsection{Soil Characteristics and Experimental Design}

The surface layer $(0-20 \mathrm{~cm})$ of Mollic Gleysol taken from an agricultural meadow exploited for hay-making, located in Kosiorów village $\left(51^{\circ} 13^{\prime} \mathrm{N} ; 21^{\circ} 51^{\prime} \mathrm{E}\right)$, southeast Poland, was used for the experiment. The soil was a peaty soil type with acidity $(\mathrm{pH})$ of 6.19 , redox potential (Eh) of $480.73 \mathrm{mV}$, electric conductivity (EC) of $197.8 \mu \mathrm{S} / \mathrm{cm}^{3}$, total organic carbon (TOC) of $27.4 \%$, and bulk density (BD) of $0.77 \mathrm{Mg} / \mathrm{m}^{3}[19,29]$. In laboratory conditions, the soil material was contaminated with the following petroleum substances: unleaded 95-octane petrol and diesel (their basic properties, according to Orlen specification, are summarized in Table 1) at a dose of $15 \mathrm{~g}$ per $10 \mathrm{~g}$ of soil. Control samples were prepared without any petroleum substances and with the addition of $15.0 \mathrm{~g}$ of distilled water per $10 \mathrm{~g}$ 
of soil. The contaminated and control soils were incubated for 6 weeks (42 days) at room temperature $\left(20^{\circ} \mathrm{C}\right)$. After this time, the following analyses were performed.

Table 1. The basic properties of petroleum substances (according to www.orlen.pl).

\begin{tabular}{cccc}
\hline Parameter & Unit & Unleaded 95-Octane Petrol & Diesel \\
\hline Carbon atoms number & - & $\mathrm{C}_{5}-\mathrm{C}_{12}$ & $\mathrm{C}_{9}-\mathrm{C}_{25}$ \\
Density & $\mathrm{g} \mathrm{cm}^{-3}$ & $0.72-0.78$ & $0.82-0.85$ \\
PAH * content & $\%$ & 20 & 11 \\
Sulphur content & $\mathrm{mg} \mathrm{kg}^{-1}$ & 10 & 10 \\
\hline \multicolumn{5}{c}{}
\end{tabular}

\subsection{Soil DNA Extraction and Molecular Identification of Bacteria}

DNA was extracted from soil samples, contaminated and control (400 mg each), after a 42-day incubation period with the application of the Gene $\mathrm{All}^{\circledR}$ Exgene $^{\mathrm{TM}}$ Soil SV mini kit (GeneAll Biotechnology Co. Ltd., Seoul, Korea) according to the manufacturer's instruction. Subsequently, PCR reactions were performed. The following primers-27F (5'-AGAGTTTGATCATGGCTCAG-3') and 518R (5'-CCAGCAGCCGCGGTAATACG-3') - were synthesized to amplify the 16S rRNA gene. 1X Phusion Flash High-Fidelity PCR Master Mix (Thermo Scientific, Waltham, MA, USA) was applied for the PCR reaction $(30 \mu \mathrm{L})$. The reaction conditions were as follows: initial denaturation $\left(98^{\circ} \mathrm{C}\right.$ for $10 \mathrm{~s}), 30$ cycles $\left(98^{\circ} \mathrm{C}\right.$ for $\left.5 \mathrm{~s}\right)$, primer annealing $\left(53^{\circ} \mathrm{C}\right.$ for $\left.5 \mathrm{~s}\right)$, and elongation $\left(72{ }^{\circ} \mathrm{C}\right.$ for $\left.40 \mathrm{~s}\right)$. Then, the amplification products were separated by electrophoresis in a $1 \%$ agarose gel, purified, and sequenced (Genomed S.A. Warsaw, Poland). The obtained results were analyzed by BLAST online comparison (http:/ / www.ncbi.nlm.nih.gov) for identification of the isolates.

\subsection{Community Level Physiological Profiling (CLPP) Analysis Using Biolog EcoPlates}

The metabolic potential of the soil bacterial communities was evaluated using the Biolog EcoPlate system (Biolog Inc., Hayward, CA, USA), composed of 31 carbon sources and water blanks [28-30]. The soil suspension for the inoculation of the wells was prepared as follows: $1 \mathrm{~g}$ of soil (contaminated and control, after a 42-day incubation period) was weighed, transferred to conical flasks holding $99 \mathrm{~cm}^{3}$ of sterile $0.9 \% \mathrm{NaCl}$ each, vortexed $\left(150 \mathrm{rpm}\right.$ for $30 \mathrm{~min}$ at $\left.25^{\circ} \mathrm{C}\right)$, and cooled $\left(30 \mathrm{~min}\right.$ at $4{ }^{\circ} \mathrm{C}$ ) as described by Pohland and Owen [31]. Afterwards, the inoculates $(120 \mu \mathrm{L})$ were transferred in each Biolog EcoPlate well and incubated in the dark $\left(28^{\circ} \mathrm{C}\right)$. The experiment included three replications. The results were read on the MicroStation ID system by Biolog ${ }^{\circledR}$. The tetrazolium violet reduction rate was used to measure the utilization rate [32]. The activities of soil microorganisms are based on all carbon sources and on grouped sources defined as amines and amides, amino acids, carbohydrate, carboxylic acid, and polymers [31]. The data collected for the whole period of EcoPlate ${ }^{\mathrm{TM}}$ incubation (0-214 h) were used to calculate the total carbon source utilization patterns [29].

\section{Results}

\subsection{Catabolic Diversity of Autochthonic Bacteria Inhabiting Soil Contaminated with Car Fuels}

The Biolog EcoPlate technique was applied to characterize changes in the soil community as an effect of car fuel contamination. The ability of soil bacteria to use particular groups of organic compounds is illustrated in Figure 1.

It was found that the control and diesel-contaminated soils displayed a similar trend in the utilization of carbon sources, whereas different preferences for carbon utilization were demonstrated by microflora inhabiting the petrol-contaminated soil. In the case of bacteria present in the control and diesel treatments, carboxylic acids (CA) were the most favored source of carbon and their utilization amounted to $21 \%-57 \%$ and $31 \%-44 \%$, respectively. Amino acids (AA) were utilized at the levels of $21 \%-25 \%$ and $16 \%-24 \%$ in the control and diesel combinations. Carbohydrates $(\mathrm{CH})$ were also an 
eagerly metabolized source of carbon and their utilization oscillated in the range of $12 \%-21 \%$ (in the control) and $21 \%-28 \%$ (in the diesel-contaminated soil). The utilization of polymers (P) achieved the level of $10 \%-12 \%$ in the control and $11 \%-20 \%$ in the diesel-contaminated soil. Amines and amides (AD) were the least preferred source of carbon for the bacteria from the control and diesel-contaminated soils, with the utilization percent of $1 \%-5 \%$ and $1 \%-9 \%$, respectively.

Completely different bacterial preferences in the use of carbon sources were found in the presence of petrol contamination (Figure 1). In this case, $\mathrm{CH}$ were the most favourable carbon substrates (18\%-59\%). However, during $1 \mathrm{~h}$ of the experiment, bacteria in the petrol-contaminated soil started to use P with metabolic effectiveness of 51\%. During the other hours (from 24 to $214 \mathrm{~h}$ ), P were used in the range of $12 \%-29 \%$.

Bacteria form the petrol-contaminated environment readily metabolized CA $(11 \%-30 \%)$ and AA $(1 \%-18 \%)$ as well. AD seemed to be the least preferred carbon source and their utilization amounted to only $1 \%-3 \%$. At $96 \mathrm{~h}$, this carbon source was not used at all.

The analysis of the carbon utilization patterns with the Biolog Ecoplate technique for control and contaminated soils are shown in Figure 2. The heat maps clearly reveal differences in the microbial activity between the treatments. Intensive utilization of the carbon substrates began to increase at 168-214, 120-144, and $168 \mathrm{~h}$ of incubation for the control, diesel, and petrol treatments, respectively.

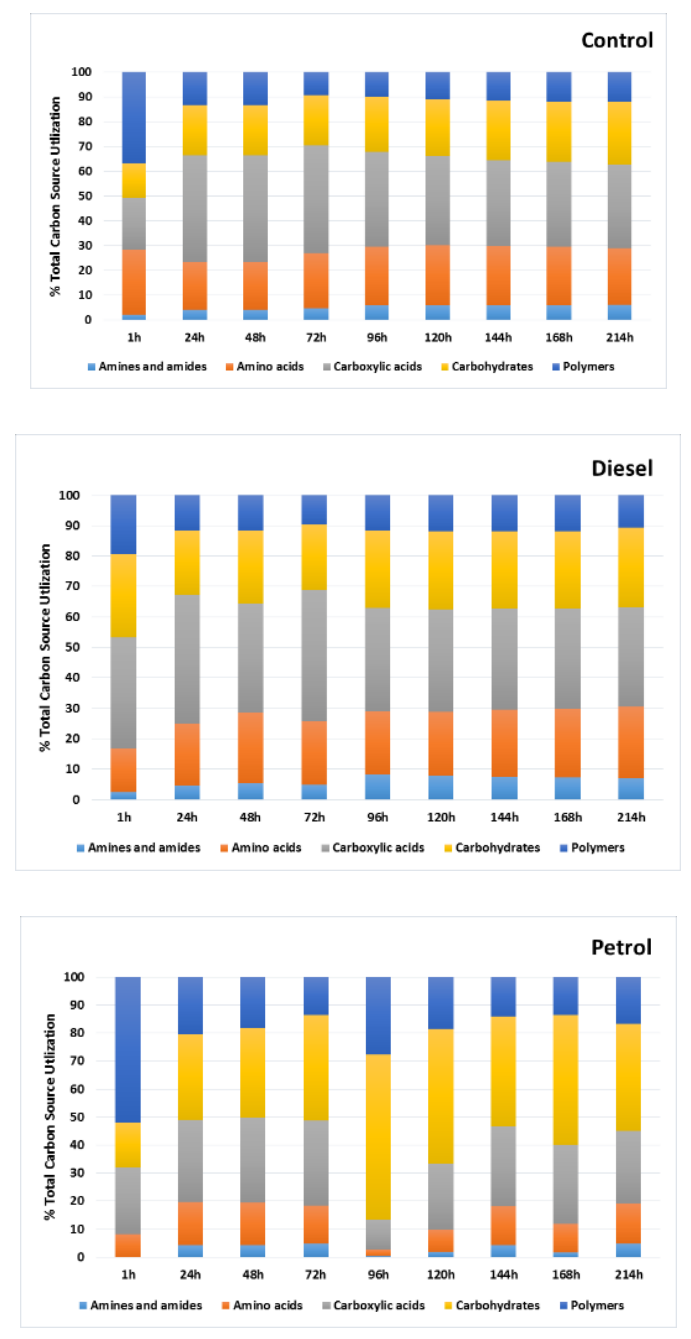

Figure 1. Total carbon source utilization response (\%) tracked for control and soils contaminated with diesel and petrol for the different carbon substrate groups. 

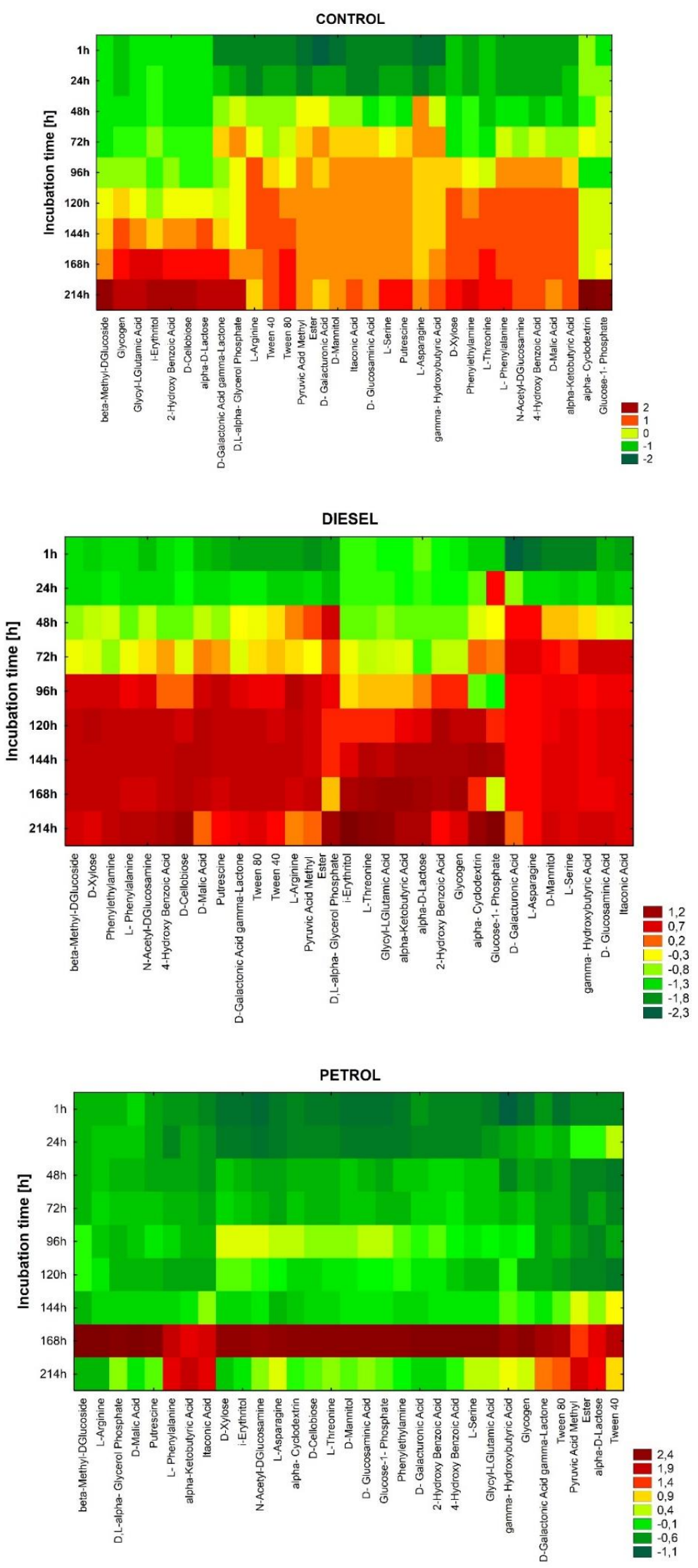

Figure 2. Biolog EcoPlate ${ }^{\mathrm{TM}}$ diagram of the intensity of carbon substrate utilization for control and soil contaminated with petrol and diesel. 
In the control sample, the bacteria first started to metabolize L-arginine after $96 \mathrm{~h}$, whilst utilization of tween 40, D-xylose, L-threonine, L-phenylalanine, $\mathrm{N}$-acetyl-D-glucosamine, 4-hydoxy benzoic acid, D-malic acid, and alpha-ketobutyric acid was noted after $120 \mathrm{~h}$ (Figure 2). Maximal intensification of carbon substrate utilization was registered between 168 and $214 \mathrm{~h}$, when bacteria from the uncontaminated soil metabolized beta-methyl-D-glucoside, glycogen, glycyl-L-glutamic acid, i-erythritol, 2-hydroxy benzoic acid, D-cellobiose, alpha-D-lactose, D-galactonic acid gamma-lactone, D,L-alpha glycerol phosphate, tween 80 , L-serine, putrescine, D-xylose, phenylethylamine, L-threonine, L-phenylalanine, alpha-cyclodextrin, and glucose-1-phosphate.

Carbon substrate utilization in the diesel-contaminated soil started from $24 \mathrm{~h}$ when the bacteria metabolized glucose-1-phosphate (Figure 2). The maximum metabolic activity was recorded from $96 \mathrm{~h}$ of incubation to the end of the experiment $(214 \mathrm{~h})$. At this time, bacteria that lived in the presence of diesel contamination most frequently metabolized the following carbon substrates: D-galacturonic acid, L-asparagine, D-mannitol, L-serine, gamma-hydroxybutyric acid, D-glucosoaminic acid, itaconic acid, L-threonine, i-erythritol, glycyl-L-glutamic acid, alpha-D-lactose, alpha-ketobutyric acid, D-cellobiose, 4-hydroxybenozic acid, $\mathrm{N}$-acetyl-D-glucosoamine, L-phyenyloalanine, phenylethylamine, D-xylose, and beta-methyl-D-glucoside.

As presented in Figure 2, the heat map obtained for the petrol-contaminated soil differed significantly from the other two and indicated strong inhibition of bacterial activity resulting from petrol contamination. In this case, the metabolic activity was recorded only at 168-214 h of incubation, when the bacteria metabolized, in particular, L-phenylalanine, alpha-ketobutyric acid, itaconic acid, pyruvic acid methyl ester, and alpha-D-lactose. After $168 \mathrm{~h}$ incubation, the bacteria intensively metabolized all sources of carbon available on the Biolog plate (Figure 2). However, their metabolic activity was afterwards inhibited by petrol contamination, which evidenced a more toxic effect exerted by the unleaded 95-octane petrol in comparison to the diesel contamination.

\subsection{Genetic Diversity of Autochthonic Bacteria Inhabiting Soil Contaminated with Car Fuels}

The variability in the microbial preferences for utilization of the various carbon sources was confirmed by the differences in the microbial structure in the studied soil. Changes in the microbial community following contamination with petrol and diesel as well as in the uncontaminated (control) soils were monitored in the PCR reaction using the $16 \mathrm{~S}$ rRNA gene (Figure 3). In each case, 545-bp PCR products were obtained.

The differences in the microbial community response depending on the contaminant type (petrol or diesel) are presented in Table 2.

Mollic Gleysol uncontaminated with the car fuels was inhabited by bacterial representatives of the genera Micrococcus, Lysinobacterium, and Bacillus. In the presence of unleaded 95-octane petrol, the following genera of indigenous bacteria were identified: Rhodococcus, Bacillus, and Microbacterium. At the same time, the soil contaminated with diesel were characterized by higher biodiversity than those treated with petrol, and the presence of Rhodococcus, Arthrobacter, Paenibacillus, and Pseudomonas representatives was confirmed.

The variability of autochthonic microflora in the control (uncontaminated) and after treatments with car fuels (petrol and diesel) is summarized in Table 3. 
Table 2. Identification of isolates based on $16 \mathrm{~S}$ rDNA sequencing data.

\begin{tabular}{|c|c|c|c|c|}
\hline Sample ID & Bacterial Genera & Isolate Name in GenBank Database & Similarity (\%) & Accession Number \\
\hline \multirow{8}{*}{ CONTROL } & \multirow{2}{*}{ Micrococcus } & Micrococcus sp. CNJ719 PL04 & 97 & DQ448712 \\
\hline & & Micrococcus sp. $76 A 3 b$ & 97 & KJ744024 \\
\hline & \multirow{3}{*}{ Lysinobacterium } & Lysinobacterium fusiformis & 99 & KY515463 \\
\hline & & Lysinobacterium sp. enrichment culture & 99 & JX992646 \\
\hline & & Lysinobacterium sphaericus & 99 & KY673682 \\
\hline & \multirow{3}{*}{ Bacillus } & Bacillus cereus & 99 & JN411317 \\
\hline & & Bacillus thuringiensis & 98 & KY368122 \\
\hline & & Bacillus tovonensis & 98 & KY352881 \\
\hline \multirow{9}{*}{ PETROL } & \multirow{3}{*}{ Rhodococcus } & Rhodococcus erythropolis strain HL-1 & 98 & KM670434 \\
\hline & & Rhodococcus sp. A35 & 98 & FM986394 \\
\hline & & Rhodococcus globerulus & 97 & AB828263 \\
\hline & \multirow{4}{*}{ Bacillus } & Bacillus anthracis & 97 & KJ721202 \\
\hline & & Bacillus mycoides & 97 & KU877669 \\
\hline & & Bacillus safensis & 99 & KY400282 \\
\hline & & Bacillus pumilus & 99 & DQ837545 \\
\hline & \multirow{2}{*}{ Microbacterium } & Microbacterium sp. IP5 & 98 & GU726546 \\
\hline & & Microbacterium oxydans & 97 & LN890176 \\
\hline \multirow{12}{*}{ DIESEL } & \multirow{2}{*}{ Rhodococcus } & Rhodococcus erythropolis strain HS9 & 98 & AY168587 \\
\hline & & Rhodococcus sp. DSD51Y & 98 & AB847903 \\
\hline & & Arthrobacter sp. ES3-54 & 99 & AB496410 \\
\hline & \multirow[t]{2}{*}{ Arthrobacter } & Arthrobacter humicola & 99 & NR041546 \\
\hline & & Arthrobacter oxydans & 99 & KP235208 \\
\hline & \multirow{4}{*}{ Paenibacillus } & Paenibacillus sp. 4-21 & 98 & HM537156 \\
\hline & & Bacillus sp. DB87 & 98 & HM566967 \\
\hline & & Paenibacillus xylanexedens & 98 & KX156222 \\
\hline & & Paenibacillus pabuli & 98 & JX293322 \\
\hline & \multirow{3}{*}{ Pseudomonas } & Pseudomonas sp. & 99 & KR673340 \\
\hline & & Pseudomonas thiveralensis & 99 & KY457754 \\
\hline & & Pseudomonas fluorescens & 99 & KT223372 \\
\hline
\end{tabular}

Table 3. Variability of autochthonic microflora in the control (uncontaminated) combination and depending on the addition of car fuels (petrol, diesel).

\begin{tabular}{cccc}
\hline Bacterial Genera & Control & Unleaded 95-Octane Petrol & Diesel \\
\hline Micrococcus & + & - & - \\
Lysinobacterium & + & - & - \\
Bacillus & + & + & - \\
Rhodococcus & - & + & + \\
Microbacterium & - & + & - \\
Arthrobacter & - & - & + \\
Paenibacillus & - & - & + \\
Pseudomonas & - & - & + \\
\hline
\end{tabular}




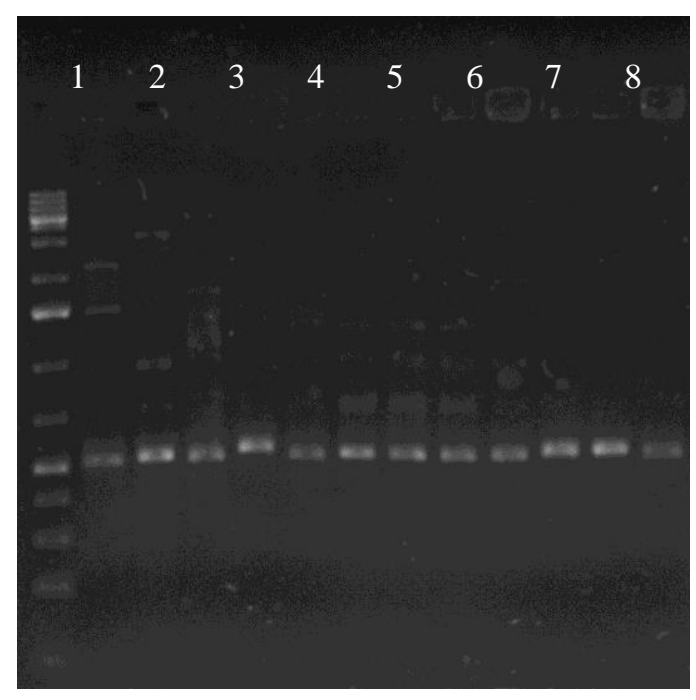

Figure 3. Agarose gel electrophoresis of PCR products (gene fragment $16 \mathrm{~S}$ rRNA): Line $1-$ molecular mass marker DNA 100-10,000 bp, 2-4 control samples, 5-9 samples contaminated with unleaded 95-octane petrol, 10-13 samples contaminated with diesel.

It was demonstrated that the autochthonic microbial structure was rearranged depending on the petroleum contaminant type because different bacterial genera and species were identified in the studied combinations.

Although Bacillus was found both in the control and the petrol-contaminated soil, the differences in the bacterial structure were demonstrated at the species level. Bacillus cereus, B. thuringiensis, and B. toyonensis inhabited the uncontaminated soil, whilst the presence of B. anthracis, B. mycoides, B. safensis, and B. pumilus was evidenced in the petrol-contaminated Mollic Gleysol. Analogous observations were reported for bacteria of the genus Rhodococcus, the presence of which was demonstrated both in the petrol- and diesel-contaminated soil. There were differences in the bacterial community structure at the species level, i.e., R. erythropolis strain HL-1, R. sp. A35, and R. globerulus were identified in the presence of the petrol contaminant, whilst $R$. erythropolis strain HS9 and $R$. sp. DSD51Y were evidenced in the presence of diesel contamination.

\section{Discussion}

We previously reported that emergence of Rhodococcus was a consequence of the 1-week incubation of Mollic Gleysol with petrol and diesel [19]. The current study evaluated the effect of longer (6-week) soil exposition to petroleum substances applied to test the resistance of bacteria to long-lasting $\mathrm{PH}$ pollution. Labud et al. [33] reported that the effect of hydrocarbon toxicity is affected by the hydrocarbon type. PHs can enter the soil environment with falling dust and they are usually strongly absorbed by the soil surface and thus hardly biodegradable [34].

The fact that diesel is a less toxic source of carbon than other automobile oils was noted by Alrumman et al. [2] and Wolińska et al. [19]. This was also proved in the current study by the Biolog EcoPlate analysis via which functional diversity was estimated. Community level physiological profiling (CLPP) yields the metabolic fingerprint of bacteria present in the soil environment and indicates the numbers of defined substrates that are oxidized by autochthonic microflora [4]. We found that the metabolic activity of bacteria inhabiting soil contaminated with diesel fuel was higher than those from the petrol-treated soil, where the functional diversity was activated only at $168 \mathrm{~h}$ of the incubation period.

Similarly, the biodiversity of bacteria was higher in the diesel-contaminated soil in comparison to the petrol treatment (Table 3). Also, Borowik et al. [7] confirmed that soil contaminated with diesel was characterized by higher dehydrogenase activity than the control, whilst petrol was found to act as a dehydrogenase inhibitor [12]. 
It should be mentioned here that dehydrogenases are intracellular enzymes present in viable microbial cells only that indicate soil biological activity $[12,35]$. They are considered to be pollution indicators, as they have no ability to accumulate in the extracellular environment [12]. Gałazka and Gałazka [14] noted that, besides dehydrogenases, alkaline and acid phosphatases displayed higher activity in chernozem and rendzina polluted with PHs. However, a study reported that soil contamination with diesel and petrol inhibited the nitrification process and that diesel oil was a much more powerful inhibitor of nitrification than petrol [5]. The experiment also lasted 42 days and at the last day nitrification was reduced by $99 \%$ and $88 \%$ for diesel and petrol contamination, respectively [5].

Many bacteria and fungi have been described as being able to utilize PHs via cometabolism [1,3, 36]. Microorganisms that have the ability to degrade PHs are referred to as hydrocarbonoclastic or oleophilic microflora [8]. Environments contaminated with PHs are home for many phylogenetically and metabolically diverse groups of microorganisms [8], which was also evidenced in our study. The most common groups summarized by Fernández-Luqueño et al. [1] were represented by the following bacterial genera, i.e., Achromobacter, Acidovorax, Aeromonas, Alcaligenes, Arthrobacter, Bacillus, Burkholderia, Cellulomonas, Flavobacterium, Methylomonas, Pseudomonas, Paracoccus, Ralstonia, Rhizobium, Rhodococcus, Sphingomonas, Shewanella, and Staphylococcus. Some of these genera were also identified in our study as Bacillus, Rhodococcus, Pseudomonas, and Arthrobacter. Hamamura et al. [22] indicated that Rhodococcus-like populations were involved in PH degradation in a majority of soils, whilst the presence of Bacillus was noted by Yousaf et al. [37], White et al. [38], Peng et al. [39], and Martin-Sanchez et al. [40]. Also, the current study confirmed this fact, as we identified the presence of Rhodococcus in soils contaminated with unleaded 95-octane petrol and with diesel. Moreover, the presence of Pseudomonas in diesel-contaminated soil was found both in our study and in other works [22,37,39,41]. Various bacteria of the genus Pseudomonas, e.g., P. aeruginosa, have frequently been found in PH-contaminated soils $[13,42,43]$. It was indicated that members of Pseudomonas have a complex system of enzymes and thus demonstrated differentiation in both metabolic and physiological properties. It is also known that Pseudomonas has the ability to produce glycolipids and biosurfactants $[43,44]$ and is often recommended as effective in bioremediation processes. Martin-Sanchez et al. [40] isolated 28 different bacterial strains from diesel-contaminated soil samples and identified 7 bacterial genera able to degrade PHs: Bacillus, Lactobacillus, Lysinibacillus, Burkholderia, Citrobacter, Acetobacter, Enterococcus, and Stenotrophomonas. However, the presence of Bacillus was noted in our study in the control and petrol-contaminated treatment, whereas Lysinibacillus was identified in the control sample only. The ability of Arthrobacter and Microbacterium to degrade alkanes in a petroleum-oil-contaminated environment via alkane hydroxylase encoding genes has also been reported [37]. In our study, Arthrobacter was found in the diesel-contaminated soil, whilst the presence of Microbacterium was proved in the petrol-contaminated soil. In general, many soil microbial consortia are involved in restoration of the biological balance in soil contaminated with hydrocarbons. Borowik et al. [17] summarized that the following bacterial genera are dominant in PH-contaminated soils: Staphylococcus, Acinetobacter, Pseudomonas, Bacillus, and Paenibacillus. The last of these genera was identified in the current study in the presence of diesel contamination.

\section{Conclusions}

Biological degradation of PHs in the soil environment is performed by a microbial consortium; thus, the knowledge of autochthonic microflora response to car fuel contaminants is extremely desirable. The microbial communities in the studied treatments were genetically and metabolically diverse. We found that the bacterial genera Bacillus, Rhodococcus, Microbacterium, Arthrobacter, Paenibacillus, and Pseudomonas have the potential to be considered as car fuel degraders. However, it is clear from our study that the autochthonic microbial structure is dependent on the petroleum contaminant type. A higher petrol toxicity to soil autochthonic bacteria than that of diesel was found. Additionally, the presence of Bacillus and Microbacterium was detected in the soil contaminated with unleaded 95-octane petrol, whereas the presence of Arthrobacter, Paenibacillus, and Pseudomonas 
was confirmed in the soil contaminated with diesel. The presence of Rhodococcus was identified in both variants of impurities, which means that this bacterial genus has the widest capability for car fuel degradation. Uncontaminated Mollic Gleysol was inhabited by Micrococcus, Lysinibacterium, and Bacillus representatives.

The metabolic activity of bacteria directly depended on the type of petroleum products as well. The unleaded 95-octane petrol contamination caused rapid inhibition of the metabolic activity of the soil bacteria. This proves that autochthonic bacteria are reluctant to use hydrocarbons contained in petrol as an additional source of carbon. The situation was different with regard to the 6-week pollution of soil with diesel. In this case, high metabolic activity of bacteria was observed, which was maintained until the end of the incubation period. Interestingly, this activity was higher than in the control (uncontaminated) soil, which proves that PHs included in diesel are characterized by a preferred carbon content for soil bacteria. We have found that the utilization gradation of the carbon sources was as follows: carboxylic acids $>$ carbohydrates $>$ amino acids $>$ polymers $>$ amines and amides.

Author Contributions: A.W. conceived and designed the experiments; N.J., A.K., A.G., J.G. and W.G. performed the experiments; A.G. and A.W. analyzed the data; A.W. and A.G. wrote the paper; Z.S. read the paper.

Funding: This study was supported by the Ministry of Science and Higher Education funds for statutory activity (1.20) and Task 1.4. Multi-Annual Programme IUNG-PIB (2016-2020).

Conflicts of Interest: The authors declare no conflict of interest.

\section{References}

1. Fernández-Luqueño, F.; Encinas, C.V.; Marsch, R.; Martínez-Suárez, C.; Vázquez-Núñez, E.; Dendooven, L. Microbial communities to mitigate contamination of PAHs in soil- possibilities and challenges: A review. Environ. Sci. Pollut. Res. 2011, 18, 12-30. [CrossRef] [PubMed]

2. Alrumman, S.A.; Standing, D.B.; Paton, G.I. Effect of hydrocarbon contamination on soil microbial community and enzyme activity. J. King Saud Univ.-Sci. 2015, 27, 31-41. [CrossRef]

3. Varjani, S.J. Microbial degradation of petroleum hydrocarbons. Biores. Technol. 2017, 223, 277-286. [CrossRef] [PubMed]

4. Chikere, C.B.; Okpokwasili, G.C.; Chikere, B.O. Monitoring of microbial hydrocarbon remediation in the soil. 3 Biotech 2011, 1, 117-138. [CrossRef] [PubMed]

5. Kucharski, J.; Tomkiel, M.; Boros, E.; Wyszkowska, J. The effect of soil contamination with diesel oil and petrol on the nitrification process. J. Elementol. 2010, 15, 111-118. [CrossRef]

6. Wyszkowska, J.; Borowik, A.; Kucharski, J. Response of Avena sativa, microorganisms and enzymes to contamination of soil with diesel oil. Plant Soil. Environ. 2015, 61, 483-488. [CrossRef]

7. Borowik, A.; Wyszkowska, J.; Kucharski, J. Functional diversity of fungal communities in soil contaminated with diesel oil. Front. Microbiol. 2017, 8, 1862. [CrossRef] [PubMed]

8. Varjani, S.J.; Gnansounou, E. Microbial dynamics in petroleum oilfields and their relationship with physiological properties of petroleum oil reservoirs. Biores. Technol. 2017, 245, 1258-1265. [CrossRef] [PubMed]

9. Mohammadi-Sichani, M.M.; Assadi, M.M.; Farazmand, A.; Kianirad, M.; Ahadi, A.; Ghahderijani, H.H. Bioremediation of soil contaminated crude oil by Agaricomycetes. J. Environ. Health. Sci. Eng. 2017, 15, 8. [CrossRef] [PubMed]

10. Moubasher, H.A.; Hegazy, A.K.; Mohamed, N.H.; Moustafa, Y.M.; Kabiel, H.F.; Hamad, A.A. Phytoremediation of soils polluted with crude petroleum oil using Bassia scoparia and its associated rhizosphere microorganisms. Int. Biodeter. Biodegr. 2015, 98, 113-120. [CrossRef]

11. Hatami, E.; Abbaspour, A.; Dorostkar, V. Phytoremediation of a petroleum-polluted soil by native plant species in Lorenstan Province, Iran. Environ. Sci. Pollut. Res. 2018, 1-8. [CrossRef]

12. Kaczyńska, G.; Borowik, A.; Wyszkowska, J. Soil dehydrogenases as an indicator of contamination of the environment with petroleum products. Water Air Soil Pollut. 2015, 226, 372. [CrossRef] [PubMed]

13. Gałązka, A.; Król, M.; Perzyński, A. The efficiency of rhizosphere bioremediation with Azospirillum sp. and Pseudomonas stutzeri in soils freshly contaminated with PAHs and diesel fuel. Pol. J. Environ. Stud. 2012, 21, 345-353. 
14. Gałąka, A.; Gałązka, R. Phytoremediation of polycyclic aromatic hydrocarbons in soils artificially polluted using plant-associated-endophytic bacteria and Dactylis glomerata as the bioremediation plant. Pol. J. Microbiol. 2015, 64, 241-252. [CrossRef] [PubMed]

15. Suja, F.; Rahim, F.; Taha, M.T.; Hambali, N.; Razali, R.; Khalid, A.; Hamzah, A. Effects of local microbial bioaugmentation and biostimulation on the bioremediation of total petroleum hydrocarbons (TPH) in crude oil contaminated soil based on laboratory and field observations. Int. Biodeter. Biodegr. 2014, 90, 115-122. [CrossRef]

16. Stefanowicz, A. The Biolog Plate technique as a tool in ecological studies of microbial communities. Pol. J. Environ. Stud. 2006, 15, 669-676.

17. Borowik, A.; Wyszkowska, J.; Wyszkowski, M. Resistance of aerobic microorganisms and soil enzyme response to soil contamination with Ekodiesel Ultra fuel. Environ. Sci. Pollut. Res. 2017, 24, 24346-24363. [CrossRef] [PubMed]

18. Grant, R.J.; Muckian, L.M.; Clipson, N.J.W.; Doyle, E.M. Microbial community changes during the bioremediation of creosote contaminated soil. Lett. Appl. Microbiol. 2007, 44, 293-300. [CrossRef] [PubMed]

19. Wolińska, A.; Kuźniar, A.; Szafranek-Nakonieczna, A.; Jastrzębska, N.; Roguska, E.; Stępniewska, Z. Biological activity of autochthonic bacterial community in oil-contaminated soils. Water Air Soil Pollut. 2016, 227, 130. [CrossRef] [PubMed]

20. Khan, J.A.; Singh, S. Evaluation of oil degradation potential of micrococcus varians. Int. J. Appl. Biol. Pharm. Technol. 2011, 2, 75-80.

21. Leilei, Z.; Mingxin, H.; Suiyi, Z. Enzymatic remediation of the polluted crude oil by Rhodococcus. Afr. J. Microbiol. Res. 2012, 6, 1213-1220. [CrossRef]

22. Hamamura, N.; Ward, D.M.; Inskeep, W.P. Effects of petroleum mixture types on soil bacterial population dynamics associated with the biodegradation of hydrocarbons in soil environment. FEMS Microbiol. Ecol. 2013, 85, 168-178. [CrossRef] [PubMed]

23. Chen, M.; Xu, P.; Zeng, G.; Yang, C.; Huang, D.; Zhang, J. Bioremediation of soil contaminated with polycyclic aromatic hydrocarbons, petroleum, pesticides, chlorophenols and heavy metals by composting: Applications, microbes and future research needs. Biotechnol. Adv. 2015, 33, 745-755. [CrossRef] [PubMed]

24. Rusin, M.; Gospodarek, J.; Nadgórska-Socha, A. The effect of petroleum-derived substances on the growth and chemical composition of Vicia faba L. Pol. J. Environ. Stud. 2015, 24, 2157-2166. [CrossRef]

25. Palmroth, M.R.T.; Koskinen, P.E.P.; Kaksonen, A.H.; Münster, U.; Pichtel, J.; Puhakka, J.K. Metabolic and phylogenetic analysis of microbial communities during phytoremediation of soil contaminated with weathered hydrocarbons and heavy metals. Biodegradation 2007, 8, 769-782. [CrossRef] [PubMed]

26. Wyszkowska, J.; Kucharski, J. Correlation between the number of cultivable microorganisms and soil contamination with diesel oil. Pol. J. Environ. Stud. 2005, 14, 347-356.

27. Garland, J.L.; Millis, A.L. Classification and characterization of heterotrophic microbial communities on the basis of patterns of community-level sole-carbon-source utilization. Appl. Environ. Microbiol. 1991, 57, 2351-2359. [PubMed]

28. Gałązka, A.; Gawryjołek, K.; Grządziel, J.; Frąc, M.; Księżak, J. Microbial community diversity and their interaction of soil under maize growth in different cultivation techniques. Plant Soil Environ. 2017, 63, 264-270. [CrossRef]

29. Wolińska, A.; Frąc, M.; Oszust, K.; Szafranek-Nakonieczna, A.; Zielenkiewicz, U.; Stępniewska, Z. Microbial biodiversity of meadows under different modes of land use: Catabolic and genetic fingerprinting. World J. Microbiol. Biotechnol. 2017, 33, 154. [CrossRef] [PubMed]

30. Frąc, M.; Oszust, K.; Lipiec, J. Community level physiological profiles (CLPP), characterization and microbial activity of soil amended with dairy sewage sludge. Sensors 2012, 12, 3253-3268. [CrossRef] [PubMed]

31. Pohland, B.; Owen, B. Biolog EcoPlate standard methods. TAS Tech. Biul. Biol. 2009, 1, 1-3.

32. Islam, M.R.; Chauhan, P.S.; Kim, Y.; Kim, M.; Sa, T. Community level functional diversity and enzyme activities in paddy soils under different long-term fertilizer management practices. Biol. Fertil. Soils 2011, 47, 99-604. [CrossRef]

33. Labud, V.; Garcia, C.; Hernandez, T. Effect of hydrocarbon pollution on the microbial properties of a sandy and a clay soil. Chemosphere 2007, 66, 1863-1871. [CrossRef] [PubMed]

34. Ziółkowska, A.; Wyszkowski, M. Toxicity of petroleum substances to microorganisms and plants. Ecol. Chem. Eng. 2010, 17, 73-82. 
35. Wolińska, A.; Rekosz-Burlaga, H.; Goryluk-Salmonowicz, A.; Błaszczyk, M.; Stępniewska, Z. Bacterial abundance and dehydrogenase activity in selected agricultural soils from Lublin region. Pol. J. Environ. Stud. 2015, 24, 2677-2682. [CrossRef]

36. Łyszcz, M.; Gałazka, A. Selected molecular methods used in assessing the biodiversity of soil organisms. Post. Mikrobiol. 2016, 55, 309-319.

37. Yousaf, S.; Andria, V.; Reichenauer, T.G.; Smalla, K.; Sessitsch, A. Phylogenetic and functional diversity of alkane degrading bacteria associated with Italian ryegrass (Lolium multiflorum) and Bridsfoot trefoil (Lotus corniculatus) in a petroleum oil-contaminated environment. J. Hazard. Mater. 2010, 184, 523-532. [CrossRef] [PubMed]

38. White, J.; Gilbert, J.; Hill, G.; Hill, E.; Huse, S.M.; Weightman, A.J.; Mahenthiralingam, E. Culture-independent analysis of bacterial fuel contamination provides insight into the level of concordance with the standard industry practice of aerobic cultivation. Appl. Environ. Microbiol. 2011, 77, 4527-4538. [CrossRef] [PubMed]

39. Peng, M.; Zi, X.; Wang, Q. Bacterial community diversity of oil-contaminated soils assessed by high-throughput sequencing of 16S rRNA genes. Int. J. Environ. Res. Public Health 2015, 12, 12002-12015. [CrossRef] [PubMed]

40. Martin-Sanchez, P.M.; Gorbushina, A.A.; Toepel, J. Quantification of microbial load in diesel storage tanks using culture- and qPCR-based approaches. Int. Biodeterior. Biodegrad. 2018, 126, 216-223. [CrossRef]

41. Borowik, A.; Wyszkowska, J. Remediation of soil contaminated with diesel oil. J. Elem. 2018, 23, 767-788. [CrossRef]

42. Saikia, R.R.; Deka, S.; Deka, M.; Banat, I.M. Isolation of biosurfactant producing Pseudomonas aeruginosa RS29 from oil-contaminated soil and evaluation of different nitrogen sources in biosurfactant production. Ann. Microbiol. 2012, 62, 753-763. [CrossRef]

43. Pacwa-Płociniczak, M.; Płaza, G.A.; Poliwoda, A.; Piotrowska-Seget, Z. Characterization of hydrocarbon-degrading and biosurfactant producing Pseudomonas sp. P-1 strain as a potential tool for bioremediation of petroleum-contaminated soil. Environ. Sci. Pollut. Res. 2014, 21, 9385-9395. [CrossRef] [PubMed]

44. Aparna, A.; Srinikethan, G.; Hedge, S. Effect of addition of biosurfactant produced by Pseudomonas ssp. on biodegradation of crude oil. Int. Proc. Chem. Biol. Environ. Eng. 2011, 6, 71-75. 